\title{
Minor Oral Surgery and Dental Extraction Procedures Management of Patients with Antithrombotic Drugs Administration
}

\author{
Manajemen Prosedur Bedah Mulut Minor dan Ekstraksi Gigi \\ pada Pasien dengan Pemberian Obat Antitrombotik
}

Dwi Riski Saputra

Oral and Maxillofacial Surgery Department, Dentistry Faculty, Jember University, Indonesia

Jl. Kalimantan 37 Kampus Tegalboto, Jember

Email: dokterdwiriski@gmail.com

\begin{abstract}
Patients who are consuming antithrombotic drugs, both anticoagulants and antiplatelet, are very at risk of bleeding complications after dental extraction or minor oral surgical treatment. But interrupting the consumption of antithrombotic drugs which are inappropriate will trigger thrombosis side effects that can endanger the patient. Therefore the operator must have good insight regarding the types of antithrombotic drugs that are often used so that the operator is able to make the right decision when we should stop or continue the surgical treatment. This review aims to optimize minor oral surgery and dental extraction prosedures management of patients on antithrombotic drug administration. Antithrombotic drugs are generally classified into two groups. Those are namely antiplatelet and anticoagulant. Antiplatelet can inhibit platelet aggregation, so that it will prevent thrombus formation in blood vessels whereas the anticoagulant group can inhibit thrombus formation by blocking the hemostasis cascade. The selection of surgical treatment on patients with antithrombotic drugs administration must be depend on both antiplatelet and anticoagulant type which is used by the patient. The conclusion are in accordance with the current literature, It's very important to make decision properly about the tromboembolic event risk if those antithrombotic drugs are discontinued, and It would stimulate bleeding event if we want to continue the drug administration.
\end{abstract}

Key Words : antithrombotic drug, minor oral surgery, thromboembolism, bleeding.

\begin{abstract}
Abstrak
Pasien yang sedang mengonsumsi obat antitrombotik, baik antikoagulan maupun antiplatelet, sangat beresiko mengalami komplikasi perdarahan pasca ekstraksi gigi atau perawatan bedah mulut minor. Namun tindakan penghentian konsumsi obat antitrombotik yang tidak tepat akan memicu efek samping trombosis yang dapat membahayakan pasien. Oleh karena itu operator harus memiliki wawasan yang baik terkait jenis obat antitrombotik yang sering digunakan sehingga operator mampu membuat keputusan yang tepat kapankah harus menghentikan atau melanjutkan perawatan bedah. Ulasan ini bertujuan untuk mengoptimalkan manajemen bedah mulut kecil dan prosedur perawatan ekstraksi gigi pada pasien dengan pemberian obat antitrombotik. Obat antitrombotik secara umum terbagi menjadi dua kelompok. Keduanya adalah antiplatelet dan antikoagulan. Antiplatelet dapat menghambat agregasi tombosit, sehingga mampu menghambat pembentukan trombus didalam pembuluh darah sedangkan kelompok antikoagulan dapat menghambat pembentukan trombus dengan memblokir kaskade hemostasis. Pemilihan perawatan bedah pada pasien dengan pemberian obat antitrombotik harus bergantung pada jenis antiplatelet dan antikoagulan yang digunakan oleh pasien. Kesimpulan sesuai dengan literatur saat ini, Sangat penting untuk membuat keputusan dengan tepat terkait resiko kejadian tromboemboli jika obat antitrombotik dihentikan, dan hal ini dapat menstimulasi terjadinya perdarahan jika kita ingin melanjutkan pemberian obat.
\end{abstract}

Kata Kunci : obat antitrombotik, bedah mulut minor, tromboemboli, perdarahan. 


\section{INTRODUCTION}

Bleeding complication during oral surgical treatment can be serious problem. The bleeding may disturb surgeon's visibility and makes the other complication. Bleeding can occur while the blood vessel is cut. Bleeding complication which is caused by trauma can be handled by applying pressure on the wound site. The surgeon usually use gauge to give adequate pressure. ${ }^{1}$

Bleeding may also occur excessively on patients with antithrombotic administration. Antithrombotic administration was the key role treatment in syndrome of acute coronary. Antithrombotic drugs can reduce platelet aggregation and inhibit clotting formation process. ${ }^{2}$ Antithrombotic drugs are generally classified into two groups. Those are namely antiplatelet and anticoagulant. Antiplatelet can inhibit platelet aggregation so that it will prevent thrombus formation in blood vessels whereas the anticoagulant group can inhibit thrombus formation by blocking the hemostasis cascade inside the body. ${ }^{3}$

Patients suffering venous thromboembolism, myocardial infarction require antithrombotic drugs to prevent acute coronary syndrome which is caused by partial or complete closure of the arterial lumen that can be detected by angiography or biopsy. ${ }^{2,45}$ The closure of the vessel lumen is caused by thrombus formation in blood vessels. Antithrombotic drugs are needed in these cases because they can inhibit platelet accumulation so that thrombus formation can be prevented. ${ }^{2,3}$

The prevalence of patients receiving anticoagulant therapy has increased significantly in recent years. Over 800.000 patients from spain, dominated by atrial fibrillation cases, have accepted anticoagulants therapy. Antiplatelet drugs are also given as general treatment for atherosclerotic disease. This medical history information exactly may help the surgeon to identify about the antithrombotic drug types which are consumed by the patient. ${ }^{6}$

The management before the surgery in patients, who have been receiving antithrombotic therapy and will undergo surgery and also invasive measures, needs very appropriate consideration especially with temporary cessation of antithrombotic drugs administration. Antithrombotic drugs administration management requires very appropriate strategy. We may perform surgery but we should avoid bleeding complications and also the thrombosis event. The operator should consider appropriately all of the risks of each anticoagulant and antiplatelet drugs temporary cessation. Proper consideration must be applied, so the adverse effect of the drugs may be decreased at the lowest level. ${ }^{7,8}$
Hemostasis is physiological response of the vessel when it is injured by stimulating clot formation to stop bleeding event. Meanwhile, thrombosis is pathological response of the body which overactivated in clot formation proscess in the absence of bleeding condition. It happens because the body maintains blood fluidity as physiological process. Hemostasis is caused by the interaction of the virchows triad. The interaction between blood flow, blood composition and endothelial cells affect the thrombotic event. ${ }^{9}$

There are three major steps in hemostasis. Those are vasoconstriction, blood clot formation, and coagulation. The first is immediate blood vessels vasoconstriction. After blood vessels are injured, paracrine hormone is released by endothelial cells which stimulates blood vessels constriction. The second is plug formation which is formed by platelet accumulation. This plug will block the blood flow at the injury site so the hemorrhage may be decreased. It may happen because the platelets, which attached to the exposed collagen surfaces, will stimulate platelet activation to release several cytokines such as serotonin, thromboxane A2, and endotelin. These cytokines may stimulate other platelets to form platelet plug. The cytokine also stimulate vasoconstriction of the blood vessels. The exposed collagen surfaces also initiate the series of coagulation cascade. The clotting cascade is generally classified into two pathways. Those are intrinsic pathway and the extrinsic pathway. In the intrinsic pathway, exposed collagen will initiate the clotting by binding factor 12 . Meanwhile, the extrinsic pathway is mainly activated by tissue factor. Tissue factor can be released by tissue injury. Fibrin fiber formation is stimulated by procoagulant factors such as fibrinogen, factor $\mathrm{V}$ and von willebrand factor which are released by platelets. In the common pathway, thrombin will convert the fibrinogen to fibers. ${ }^{10}$ These fibers will become mesh like, and it can bind the platelets together. These fibrin fibers also can stick the platelet to the inside wall of the blood vessels, where the injury site is located. ${ }^{9}$

Thrombosis is pathological response of the body that overactivated in the clot formation process in the absence of bleeding condition. Thrombosis occurs in the syndrome of acute coronary which becomes the primary cause of any cardiovascular disease. Thrombosis can be stimulated by lipid which is covered by atheromatous plaque. Atheromatous plaque can be cracked and release lipid constituent. This may also stimulate platelets attachment to the injury site which could be activated and it stimulates further platelet accumulation. When the platelets are around the plaque, it will change their fabrics of glycoprotein 
$\mathrm{IIb} / \mathrm{III}$ a receptors to bind fibrinogen. This formation will make a complex platelet linkage. These platelet aggregations could occlude partially or the lumen of blood vessels. Thus, this condition may obstruct blood flow. ${ }^{11}$

Antithrombotic drugs have several mechanisms which can inhibit platelet aggregation, fibrin fibers formation and ruin the clots which have been formed. In general, antihrombotic drugs are divided into two groups. Antithrombotic drugs are generally classified into two groups. Those are namely antiplatelet and anticoagulant each of which has function of fibrin formation and thrombus aggregation. ${ }^{3}$

Antiplatelet inhibits platelet aggregation which will prevent thrombus formation in blood vessels. Antiplatelet drugs include: aspirin and indobufen inhibit TXA2 synthesis, clopidogrel, prasugrel and ticagrelor that inhibit ADP receptor activation, dypiridamole and cilostazol that decrease $\mathrm{Ca}^{++}$by elevating cAMP, abciximab, tirofiban, and eptifibatide that block GP Iib/IIIa receptors. ${ }^{12,13}$

The anticoagulant group inhibits thrombus formation by inhibiting the hemostasis cascade in the body. This anticoagulant group is divided into four classes, namely vitamin $\mathrm{K}$ antagonists (include warfarin), heparin (include unfractionated and low molecular heparin), Novel or direct oral anticoagulants comprising $\mathrm{Xa}$ factor inhibitors and thrombin inhibitors. ${ }^{14,15}$

For many decades, warfarin and heparin which are combined with aspirin as anti plateletes are usually used for acute coronary syndromes. Recently, practitioners have developed oral anticoagulant drugs such as novel direct oral anticoagulant drugs. These drugs may specifically inhibit thrombin or factor Xa which are coagulation enzymes. One of the advantage using these drugs are minimal bleeding event. Moreover, this novel oral anticoagulant drugs are better preventing agent for thromboembolism.

Heparin is generally divided into two groups. Those are unfractionated heparin and low molecular weight heparin. Heparin is usually used for venous thromboembolism treatment and acute coronary syndromes. There is a difference between unfractionated heparin and low molecular weight heparin in their application. Unfractionated heparin is usually used intravenously whereas low molecule heparin is usually used subcutaneously. Both anticoagulants have a fast onset anticoagulation. ${ }^{16}$ Heparin can stimulate hemorrhagic effect, because it can bind antithrombin III and deactivates factors IIa dan Xa. ${ }^{17}$

Vitamin $\mathrm{K}$ antagonists has been used as anticoagulation treatment for stroke prevention for more than fifty years. As long anticoagulant therapy, warfarin has been proven to be effective therapy on stroke prevention. Vitamin $\mathrm{K}$ antagonist drugs could reduce the stroke rate until $60 \%$. Vitamin K antagonist drugs could inhibit posttranslational carboxylation of coagulation factors. Vitamin $\mathrm{K}$ antagonist could inhibit Xa factor, therefore it can prevent prothrombin to be thrombin. ${ }^{18}$

Novel or new direct oral anticoagulant (DOAC) drugs have been found as advance anticoagulant drugs which have spesific target in coagulation cascade. DOAC has been proven as good as vitamin $\mathrm{K}$ anticoagulant (warfarin) drugs outcome, but it has minimal bleeding effect than vitamin $\mathrm{K}$ anticoagulant. Many reports which have reported that DOAC has been proven very effective as stroke prevention therapy. It can prevent the atherothrombotic event which occurs after acute coronary syndrome. ${ }^{19}$

All of novel or new direct oral anticoagulant (DOAC) types have a selective action to coagulation factor. Apixaban, edoxaban and rivaroxaban can inhibit factor Xa, whereas dabigatran inhibit especially thrombin. ${ }^{19}$ One of the difference between DOAC and vitamin $\mathrm{K}$ antagonist is the half life of the drug. Warfarin has longer half life than DOAC. Warfarin has half life which is 40 hours, whereas DOAC has shorter half life which is eight to twelve hours. Morever, DOAC has fast onset after oral administration. DOAC has fast onset which is in two to four hours. ${ }^{19}$

Aspirin is antiplatelet drug which is the most prescribed. Aspirin is usually used in ischemic heart diseases, because it can inhibit cyclooxygenase activity in arachidonic acid metabolism. Aspirin inhibits cyclooxygenase 2 enzym to stimulate the thromboxane A2 production which is strong chemoattractant for platelet recruitment. Aspirin can be used as a single drug or used in combination in dual antiplatelet therapy with clopidogrel. Aspirin is usually used in combination with anticoagulant drugs such as heparin and warfarin. ${ }^{20}$

Clopidogrel is antiplatelet drug which is member of thienopyridines. Clopidogrel is usually used in myocardial infarction and also unstable angina for preventing vascular occlusive. Moreover clopidogrel was developed by chemical modifying of previously adenosine diphosphate antagonist drug which is ticlopidine. Clopidogrel also has minimal bleeding effect than ticlopidine. ${ }^{20}$

Clopidogrel has selective action to the adenosine diphosphate, so that it has capacity to inhibit platelet accumulation. Moreover clopidogrel can inhibit the activation of the glycoprotein GPIIb/IIIa receptor which is located on the platelet surface and become the major receptor for fibrinogen. ${ }^{20}$ 


\section{DISCUSSION}

Bleeding risks management in dental surgical treatment of patient on antithrombotic drugs therapy should be considered properly to prevent thromboembolic or bleeding complication. Incorrect termination of antithrombotic drug can stimulate thromboembolic event, whereas bleeding complication may occur if the operator continue the antithrombotic drug consumption. ${ }^{2,14}$

The first, the operator must know about the medical history of the patient and how long the patient will receive antithrombotic drug therapy. Patients who have used prosthetic heart valves and also arterial or venous stent require cardiologist written permission to alter the antithrombotic medication. Patients who have used prosthetic heart valves and also arterial or venous stent has higher risk of bleeding complication. For the patients who receive short life antithrombotic drugs therapy, dental extraction or minor oral surgical treatment can be delayed until the end of antithrombotic medication, whereas the patients who receive long life antithrombotic drugs therapy, the drugs therapy can be stopped temporarily. ${ }^{14}$

The second, the operator must know the type of antithrombotic drugs which is used by the patient, because the decision is also determined by this aspect. Such as aspirin, ibuprofen and diclofenac have been proven that can exacerbate the bleeding complication after its administration. Moreover, patients receiving aspirin medication as single drug don't need to stop consuming the drug temporarily, because it can be handled by using local hemostatic. ${ }^{13}$

Local hemostatic agent is usually used in dental practice to stop bleeding occurrence. It can be used after tooth extraction and also odontectomy surgery which is applied in the socket before we put suture. Local hemostatic is generally classified in to two category, active agent (such as thrombin, tannic acid, albumin, and etc), and passive agent (such as collagen, cellulose, and gelatin). The active agent of hemostatic can influence directly to coagulation cascade so it can stimulate the clot formation, whereas the passive agent provide a framework for platelet aggregation. ${ }^{1}$

The patients, who consume anticoagulant medication, will have anticoagulant effect until the fifth day. Therefore, if the patient will undergo dental extraction or minor oral surgical treatment, it should be delayed until the fifth day. Vitamin $\mathrm{K}$ antagonist such as warfarin has longer half-life which is 40 hours, whereas novel direct oral anticoagulant has shorter half-life which is eight to twelve hours. According to those informations, if the patients have been receiving novel direct oral anticoagulant medication, the surgical treatment can be performed earlier after the termination of the drug consumption, whereas the patients who have been receiving medication have to delay the surgical treatment until the fourth day. ${ }^{14}$

Patients who don't use prosthetic valve or arterial and venous stent are not allowed to alter the anticoagulant medication. Moreover, the patient appointment should be performed in the morning because bleeding complication could be handled adequately during the appointment. ${ }^{14}$

Almost the same as management of patients receiving anticoagulant drugs, the operator must know the antiplatelet drug types that have been used by the patient. Because there is no single report that temporary aspirin cessation can result in thromboembolic events, the dentist may discontinue aspirin medication without the cardiologist permission. ${ }^{13}$ Moreover, some studies had proven dental surgical treatment on patients, who have used aspirin medication in single or dual platelet, can be safely performed when the operator uses appropriate local hemostatic agents. $^{13}$

Another research report had also reported that appropriate local hemostatic could prevent bleeding event in patients using antiplatelet drugs. Lillis et al (2011). monitored 111 patients receiving antipletelet medication. Those patients consist of 42 patients using aspirin, 36 patients using clopidogrel, and 42 patients using dual antiplatelet drugs (aspirin combined with clopidogrel). All of those patients had performed dental extraction and the bleeding complications were successfully handed by applying local haemostatic agent. ${ }^{21}$

Although using appropriate local hemostatic agent is recommended to prevent bleeding complication, the dentist should consider the number and the regional of the teeth which will be extracted. The first, teeth extraction, which will be performed in the single session, shouldn't more than 3 teeth to prevent bleeding complication. The second, if we will extract molar teeth which is located in the same regional of the dental arch, the dentist is only allowed to extract one molar tooth. It is not allowed to extract two-molar adjacent teeth in the same session. ${ }^{13}$

It can be concluded that a dentist requires sufficient knowledge related to minor oral surgery and dental extraction procedures management of patients using antithrombotic drugs. The dentist should understand the types, effects of antithrombotic drugs which is used by patient, so the dental management can be done properly. 


\section{REFERENCES}

1. Santhosh KMP. Local hemostatic agents in the management of bleeding in oral surgery: Article Review. Asian J pharm clin res 2016; 9(3): 35-41.

2. Costa F, Brugaletta S. Antithrombotic therapy in acute coronary syndrome: striking a happy medium. Rev esp cardiol 2018; 71(10): 782-829.

3. Syam AF, Suseno D. Antithrombotic management in endoscopic procedures: article review. Indonesian $\mathrm{j}$ of internist 2018; 5(1): 47.

4. Sacco RL, Kasner SE, Broderick JP, et al. An updated definition of stroke for 21th century. Stroke 2013; 44: 2064-89.

5. Onwordi EN, Gamal A, Zaman A. Anticoagulant therapy for acute coronary syndromes. Interventional cardiology review 2018; 13(2): 87-92.

6. Vivas D, Roldan I, Ferrandis R, et al. Perioperative and Periprocedural Management of Antithrombotic Therapy: Consensus Document of SEC. Rev esp cardiol. 2018; 71(7): 554.

7. Van VJJ, Makris M. Management of peri-operative antithrombotic therapy. Anaesthesia 2015; 70(1): $58-67$.

8. Douketis JD, Spyropoulos AC, Spencer F, et al. Perioperative management of antithrombotic therapy, 9th ed: American College of chest physicians evidence-based clinical practice guidelines. Chest 2012; 141(Suppl.1): e326S-50S.

9. Fareed J, Iqbal O. Anticoagulation and hemostasis in neurosurgery. Switzerland: Springer, 2016: 3-15.

10. Ogle OE, Swantek J, Kamoh A. Hemostatic agents. Dent clin north am 2011; 55: 433-9.

11. Stone J, Hangge P, Albadawi $\mathrm{H}$, et al. Deep vein thrombosis: pathogenesis, diagnosis, and medical management. cardiovasc diagn ther 2017; 7(Suppl 3): S276-S284.
12. Becker DE. Antithrombotic Drugs: Pharmacology and Implications for Dental Practice. Anesth Prog 2013; 60: 72-80.

13. Dinkova A, Kirova D, Delev D. Dental management and bleeding complications of patiens on longterm oral antiplatelet therapy. J of IMAB 2013; 19 (2): 298.

14. Lee JK. Dental management of patients on antithrombotic agents: review article. J korean assoc oral maxillofac surg 2018; 44: 144-145.

15. Abuqayyas S, Raju S, Bartholomew JR, et al. Management of antithrombotic agents in patients undergoing flexible bronchoscopy. Eur respir rev 2017; 26: 3-16.

16. Mulloy B, Hogwood, Gray E, et al. Pharmacology of Heparin and Related Drugs. Pharmacol Rev 2016; 68:78.

17. Nutescu E, Burnett A, Fanikos J, et al. Pharmacology of anticoagulants used in the treatment of venous thromboembolism. J thromb thrombolysis 2016; 41: 15-31.

18. Zirlik A, Bode C. Vitamin K antagonists: relative strengths and weaknesses vs direct oral anticoagulants for stroke prevention in patients with atrial fibrillation. J thromb thrombolysis 2017; 43: 365379.

19. Almarshad F, Alaklabi A, Bakhsh E, et al. Use of direct oral anticoagulants in daily practice. Am j blood res 2018; 8 (4): 57-72.

20. Hartayu T, Setyaningsih D. The Effectiveness of Clopidogrel As An Antithrombotic Compared To Ticlopidine And Aspirin (Meta-Analysis). Jurnal farmasi sains dan komunitas 2017; 14(1), 66.

21. Lillis T, Ziakas A, Koskinas K, et al. Safety of dental extractions during uninterrupted single or dual antiplatelet treatment. Am J Cardiol 2011; 108(7): 964967 